\title{
MACRONUTRIENT INTAKE, VITAMIN C, PURINE INTAKE, BODY MASS INDEX AND URIC ACID LEVELS IN MAN (AGED 26-45 YEARS OLD) IN RW 05 SUB-DISTRICT BUKIT DURI JAKARTA
}

\author{
Yulia Wahyuni $^{1^{*}}$, Umi Kholifah ${ }^{2}$, Idrus Jus'at ${ }^{3}$ \\ 1,2,3 Nutrition Study Program, Faculty Of Health Sciences University Of Esa \\ Unggul, Jakarta, Indonesia \\ * Presenting author, e-mail : ${ }^{1}$ yulia.wahyuni@esaunggul.ac.id; \\ 2umirachman92@gmail.com
}

Date Submitted: 02 December 2019; Date Accepted: 30 December 2019

\begin{abstract}
Hyperurisemia is a condition that uric acid levels in blood above the normal value. Uric acid levels are influenced by consumption of purines, carbohydrate intake, protein, fat, vitamin $\mathrm{C}$ and Body Mass Indeks (BMI). The purpose of study was to describe correlation of consumption of purine, carbohydrate intake, protein, fat, vitamin C, BMI and uric acid level in man (aged 26-45 years old) in RW 05 subdistrict Bukit Duri Jakarta, 2017. This study was used a cross sectional design with sample of 56 man aged 26-45 years old. Data of carbohydrate, protein, fat,vitamin C and purine intake were collected from Food Frequency Questionaire semi quantitative used food phothograph. BMI was measured by is a person's weight in kilograms divided by the square of height in meters. Uric acid levels was measured by GCU Easy Touch. Data was analyzed by Pearson's test and One-Way ANOVA test. There are 56 respondents, as many as $57.1 \%$ had normal uric acid levels. While $37.5 \%$ respondents have high uric acid levels. Based on statistical Pearson's test showed there are significant relation between consumption of purine $(0,001)$, protein intake $(0,001)$, fat intake $(0,001)$, vitamin $\mathrm{C}(0,008)$ and uric acid levels. There is not relation between carbohidrat intake $(0,259)$, IMT $(0,117)$. Another One-Way ANOVA test founded that there are differences consumption of purine, carbohydrate intake, protein, fat, vitamin $\mathrm{C}$ based on uric acid levels $(\mathrm{p}<0,020)$. The higher intake of the purin, protein and fat increases uric acid levels. The higher intake of the vitamin $\mathrm{C}$ can reduce uric acid levels
\end{abstract}

Keywords: Uric acid, nutrition, purin, BMI

ISSN 1979-7621 (Print). ISSN 2620-7761 (Online).

\section{INTRODUCTION}

This time has been a shift in terms of epidemiology, which once more emphasizes the infectious disease evolved into non contagious diseases are currently the attention as one health problem both nationally and globally (Soejoeti, Sunanti Z, 2009). The prevalence of noncommunicable diseases in Indonesia increased as hypertension, heart disease, stroke, diabetes 
mellitus, asthma and joint disease / arthritis (Riskesdas, 2013).

Gout is one of degenerative diseases that is caused by elevated levels of uric acid in the blood called hyperuricemia. Uric acid is a compound produced by the body that normally present in the blood and urine. Uric acid is also the end product of protein metabolism of foods containing purine that is one of the components of nucleic acids contained in the nucleus (Hayman \& Marcason, 2009). Men have a higher risk of hyperuricaemia than women where men have a 3-4 times higher risk than women. The ratio will decrease when a woman enters menopause (Lingga, 2012). Riskesdas data in 2013 showed the prevalence of joint disease at the age of 23-34 years who were diagnosed with symptoms of health personnel by $16.1 \%$, age $35-44$ of $26.9 \%$. The prevalence of joint disease in South Jakarta of $24.1 \%$. Bukit Duri is one of the villages that were in Tebet, South Jakarta. Based on monthly reports Puskesmas Village Bukit Duri in October 2016 that the prevalence of hyperuricemia approximately $5.16 \%$.

Several factors are associated with increased gout include consumption of food sources of purines, carbohydrate, protein, fat, vitamin $\mathrm{C}$ and body mass index. Consumption of foods high purine sources will lead to increased production of uric acid (Choi, Karen, Elizabeth, Walter, \& Gary, 2004). Protein intake in patients with gout can accelerate the production of purine endogenous that can trigger the breakdown of purines in the body and lead to increased blood uric acid levels (Villegas etal.,2012). High fat content in the diet will cause acidosis that can menghambatan excretion of uric acid by the kidneys (Hartono, 2004). Vitamin $C$ can increase the removal of uric acid through the kidneys (Soeroso, Joewono \& Hafid Algristian, 2011). Obesity is a risk factor that contributes to the occurrence of gout. Past research has shown the risk of gout increased with increasing BMI $\geq 25$ (Choi, Mount \& Reginato, 2005).

Research on the levels of uric acid in Jakarta is still rarely performed. Based on the results Riskesdas (2013) The prevalence of joint disease in South Jakarta of 24.1\%. Bukit Duri is one of the villages that were in Tebet, South Jakarta. Based on monthly reports Puskesmas Village Bukit Duri in October 2016 that the prevalence of hyperuricemia approximately $5.16 \%$.

\section{METHODS}

The study was conducted in RW 05, Village of Bukit Duri in December 2016 January 2017. This study included public nutrition research and observational with design cross sectional. The population in this study were males aged adults (26-45 years) in RW 05 Sub Bukit Duri. Sampling by means of cluster sampling,obtained by 56 respondents. Criteria for inclusion in this study were men aged 26-45 years old, willing to be sampled by filling out form, aninformed consentthere are taking any medications, do not suffer from hyperuricemia, hypertension, type 2 diabetes and kidney disorders, do not consume alcohol. The exclusion criteria were applied are consuming alcohol, resigned when the research.

Independent variable are consumption of food sources of purines, carbohydrate, protein, fat intake, vitamin $\mathrm{C}$ intake and BMI. Dependent variable is uric acid levels. Data collected include research respondent characteristics such as age, occupation, education, measurement results uric acid levels, consumption of food sources of purines, carbohydrate, protein, fat intake, vitamin $\mathrm{C}$ intake and BMI. The data was obtained using a questionnairerespondent characteristics. Uric acid levels obtained by examination using the tool Easy Touch GCU. Body Mass Index is the measurement of weight and height. The Data food intake (carbohydrates, proteins and fats consumption of food sources of purines and vitamin C) obtained by Food Frequency semiquantitativeQuestionnaire.Data consumption of food sources of purines are calculated based on the table grouping of foodstuffs according to levels of purines. Carbohydrate, protein, fat, 
vitamin $\mathrm{C}$ obtained converted into grams and then processed using softwarenutrisurvey.

Data analysis using SPSS. The bivariate analysis using correlation Pearson test and one way anova test.

\section{RESULTS AND DISCUSSION}

Respondents in this study amounted to 56 people. The age of respondents ranged 26-45 years. Based on MOH (2009) adult age categories are grouped into two groups: early adulthood (26-35 years) and late adulthood (3645 years). The majority of respondents aged between 36-45 years (66\%). The frequency distribution of respondents by category of research variables can be seen in the table.

Based on Table 1 it can be seen that the respondents uric acid levels ranged from 2.6 to $11.0 \mathrm{mg} / \mathrm{dl}$ with a mean of $6.37 \pm 1.87 \mathrm{mg} / \mathrm{dl}$. This study showed that out of 56 respondents mostly had normal uric acid levels of $57.1 \%$ (n $=32$ ), while respondents who have high uric acid levels by $37.5 \% \quad(\mathrm{n}=21)$.

Table 1. The mean of the consumption of food sources of purines, carbohydrate, protein, fat, vitamin c and body mass index based on the uric acid levels

\begin{tabular}{lccc}
\hline \multicolumn{1}{c}{ Variable } & Mean \pm SD & Minimum & Maximum \\
\hline uric acid levels (mg / dl) & $6.37 \pm 1,87$ & 2.6 & 11.0 \\
consumption of food sources of purines $(\mathrm{mg})$ & $842.20422 .67 \pm$ & 340.48 & 2267.87 \\
carbohydrate intake (grams) & $392.78 \pm 93.49$ & 184.40 & 632.20 \\
Protein intake (gram ) & $86.4731 .04 \pm$ & 23.10 & 147.25 \\
fat intake (grams) & $84.56 \pm 40.07$ & 12.70 & 181.10 \\
vitamin C intake (mg) & $83.6040 .90 \pm$ & 17.0 & 238,0 \\
Body mass index (kg / m2) & $22.46 \pm 3.95$ & 17.37 & 35.59 \\
\hline
\end{tabular}

Consumption of food sources of purines respondents ranged from 340.48 to $2267.87 \mathrm{mg}$ with a mean of $842.20 \pm 422.67 \mathrm{mg}$. Food sources of purines are being consumed as meat, chicken, beans, tofu, tempeh, cassava leaves, spinach, kale, melinjo / chips and leaves melinjo. Respondents who had normal uric acid levels consume food sources such lower purine in the form of vegetable protein (tofu and tempeh). Consumption of food sources of purines majority of respondents, including normal. Normal purine intake of 500-1000 mg per day (Diantari \& Chandra, 2013). Carbohydrate intake respondents ranged from 184.40 to 632.20 grams with the average of $392.78 \pm 93.49$ grams. Respondents carbohydrate intake come from complex carbohydrates and simple. Complex carbohydrates are consumed like rice, cassava, sweet potatoes, potatoes, bread and instant noodles. Protein intake respondents ranged from 184.40 to 632.20 grams with the average of $86.47 \pm 31.04$ grams. Respondents varies the intake of protein derived from animal and vegetable protein. Respondents who coined the high protein intake more often consume animal protein $2 \mathrm{x}$ per day such as meat, chicken, eggs and fish.

Respondents fat intake ranged from 12.70 to 181.10 grams with the average of 84.56 \pm 40.07 grams. RDA of fat by the Department of Health (2013) of 82 grams per day. Fat intake when compared with AKG respondents generally included more. Based on the results of the recall $2 \times 24$ hours to note that respondents who have high fat intake $(52 \%)$ because more often consume foods that are processed by methods such as frying and food bersantan tripe soup, green bean porridge made of coconut milk and coffè. Respondents chose deep fried food (bakwan, fried plantains, fried tempeh) as a distraction. Vitamin $\mathrm{C}$ intake ranged from 17.0 to $238.0 \mathrm{mg}$ with rerata83,60 $\pm 40.90 \mathrm{mg}$. Figures Nutritional Needs of vitamin C according to the $\mathrm{MOH}$ (2013) to adulthood at about $90 \mathrm{mg}$ per day. Intake of vitamin $\mathrm{C}$ 
respondents there were 35 people who had a vitamin $\mathrm{C}$ intake of $<90 \mathrm{mg}$ per day. Respondents had a vitamin $\mathrm{C}$ intake below the RDA for rarely ate vegetables. IMT respondents ranged from 17.37 to $35.59\left(\mathrm{~kg} / \mathrm{m}^{2)}\right.$ with a mean of $22.46 \pm 3.95 \mathrm{~kg} / \mathrm{m}^{2}$, including normal. The purpose of study was to describe correlation of consumption of purine, carbohydrate intake, protein, fat, vitamin $\mathrm{C}, \mathrm{BMI}$ and uric acid level in man (aged 26-45 years old).

Based test for normality using the Kolmogorov-Smirnov, the data obtained uric acid levels, consumption of food sources of purines, carbohydrate, protein, fat, vitamin $\mathrm{C}$ and $\mathrm{BMI}$ normal distribution. The results of further analysis usingcorrelation. PearsonBased on the analysis usingcorrelation Pearson was found a significant relationship consumption of food sources of purines $(p=0.000), \operatorname{protein}(p=0.000)$, fat $(p=0.000)$, vitamin $\mathrm{C}(p=0.008)$ and uric acid levels. While carbohydrate intake and body mass index was not significantly associated with uric acid levels $(p>0.05)$.

Table 2. Relationship consumption of purines, carbohydrate intake, protein, fat, vitamin $\mathrm{C}$, body mass index and uric acid levels

\begin{tabular}{lcc}
\hline & Variable & \multicolumn{2}{c}{ uric acid levels } \\
\cline { 2 - 3 } & $\mathrm{r}$ & $p$ \\
\hline Purine & 0,733 & 0,001 \\
Carbohydrate Intake & 0,154 & 0,259 \\
Protein Intake & 0,583 & 0,001 \\
Fat Intake & 0,568 & 0,001 \\
Vitamin C Intake & $-0,348$ & 0,008 \\
Body Mass Index & 0,212 & 0,117 \\
\hline
\end{tabular}

This study found that the consumption of food sources of purines effect on uric acid levels respondents. Foods containing purine substances when entering in the body will undergo metabolic processes with the end result of uric acid (Murray, Granner, \& Rodwell, 2006). This study is in line with research conducted by Diantari (2013) on women after 50-60 years also found a significant relationship between the intake of purine to uric acid levels $(p=0.000)$. Serupan research states that more hyperuricemia was found in respondents with the consumption of foods high in purines are often $(20.4 \%)$ diabnding rare (7.5\%) (Lina \& Setiyono, 2014).

Respondents with high uric acid levels more often consume food high purine sources such as offal, duck. Uric acid production increases due to exogenous excess can be caused by high intake of purine-rich foods such as meat and seafood (Kurnia, 2010).
Purin is one of the organic basic compounds that make up the nucleic acid or nucleus of the cell and included in the group of amino acids, the building-blocks of proteins. Nucleic acids are released in the intestinal tract will be parsed to mononucleotide by enzyme ribonuclease, deoksiribonukliease and polinukleotidase. Then nukleotidase and phosphatase enzymes hydrolyze mononucleotide into nucleotides that can then be absorbed or broken down by the enzyme phosphorylase more lanjuat intestinal into purine and pyrimidine bases. The process of formation of uric acid metabolism largely endogenous purine nucleotide, guanosine monophosphate (GMP), inosine monophosphate (IMP) and adenosine monophosphate (AMP). The enzyme xanthine oxidase catalyzes hypoxantin and guanine with the final product uric acid. Humans do not have enzymes urikase, so the final product of the catabolism of purines is in the form of uric acid (Murray, Granner, \& Rodwell, 2006). 
correlation test results Pearson showed no statistically significant association of carbohydrate intake and uric acid levels respondents, $p=0.259$ (sig> 0.05 ). This is contrary to the theory. No significant relationship carbohydrate intake and uric acid levels is due to the intake of carbohydrates normal most of the respondents (52\%) when compared AKG. This research is also still limited to the total carbohydrate intake so it can not separate analysis of fiber and fructose thus affecting not their relationship carbohydrate intake and uric acid levels.

According to Murray, Granner, and Rodwell (2006) simple carbohydrates such as fructose also can cause increased levels of uric acid. Fructose has a direct effect with uric acid metabolism. Increased intake of fructose can increasesynthesis de noco purinethat increase uric acid levels. Respondents in this study have the habit of drinking instant coffee and sweet tea 3-4 times a day. Sugar content found in coffee and sweet tea including simple carbohydrates, simple carbohydrates which have had an effect on uric acid levels. Uric acid is more soluble in alkaline urine so that foods containing hidtratarang and less fat with an adequate amount of fluids can help spending excess uric acid (Hartono, 2004).

Men who consume beef or lamb can increase the risk of uric acid 21\% (Dianati, 2015). Food sources of animal protein has a high purine content which can increase uric acid levels in the urine of 0.5 to $7.5 \mathrm{~g} / \mathrm{ml}$ (Choi, Karen, Elizabeth, Walter, \& Gary, 2004). Respondents with low protein intake prefer vegetable protein as a side dish. Vegetable protein is more often consumed by respondents such as tofu and tempeh $1-3 x$ per day. This could be because most residents of Bukit Duri Village community economic level spread from the middle class to the poor category. The intake of protein and uric acid levels were statistically significant relationship $(p=0.000)$. Sources of protein-containing purine many associated with the incidence of hyperuricemia, both vegetable protein and animal protein (Hayman \& Marcason, 2009). Similar research showed the animal protein intake is associated with increased blood uric acid levels $(p<0.05)$ (Mulyasari, 2015)

It can support the respondent becomes excessive fat intake. Research Ilyas, Suprihartono, \& Goddess (2014) found samples with high fat intake had a 3:38 time experience hyperuricemia risk than samples with lower fat intake.

This study shows the results correlation statistical ofPearson value of $p=$ 0.000 ( $\mathrm{sig}<0.05$ ), which means there is a significant relationship intake of fat and uric acid levels. Fat can inhibit the excretion of acid so that for patients with hyperuricemia higher fat intake higher uric acid levels as a result of inhibition of uric acid excretion via urine. Fat can also improve insulin resistance which can result in renal reabsorption of uric acid (Wortman, 2000). High fat content in the diet will lead to acidosis due to the formation of ketone bodies are the result of the catabolism of fat consisting of acid asetoasenat, acid $\beta$ - hydroxybutyrate and acetone so as to make the urine more acidic and causes inhibition of excretion of uric acid by the kidneys as a result of uric acid levels in the blood increased (Hartono, 2004).

Correlation test results Pearson in the study showed no association of vitamin $\mathrm{C}$ intake and negatively correlated uratdan acid levels means increasing intake of vitamin $\mathrm{C}$ can lower blood uric acid levels. The average intake of vitamin $\mathrm{C}$ respondents was 83.60 mg per day. Vegetables and fruits are a good source of vitamin C. Low intake of vitamin $\mathrm{C}$ in these respondents because most rarely eat vegetables and fruits, causing vitamin $C$ intake are lacking. Vitamin $\mathrm{C}$ has an impact on the levels of uric acid in lowering uric acid levels. The same thing was found in a cohort study in the United States in 2008 which showed that supplementation of vitamin C of $500 \mathrm{mg} /$ day for two months can lower blood uric acid levels of $0.5 \mathrm{mg} /$ 
dl (Gao, Curhan, Forman, Ascherio, \& Choi, $2008)$.

Vitamin $\mathrm{C}$ provides beneficial effects urikosurik to increased excretion of uric acid, other than that vitamin $\mathrm{C}$ can reduce serum uric acid concentration is high can cause efflorescence in joints and kidneys that triggers gout and kidney stones. Vitamin $\mathrm{C}$ reduces serum uric acid by increasing glomerular filtration. Vitamin $\mathrm{C}$ and uric acid is reabsorbed through thetransport anion exchange in the proximal tubule. This is to improve glomerular filtration including antioxidant effects that may reduce ischemic microvascular in glomeruli and trigger an increase in blood flow, dilation / dilating arteries afferent and competition reabsorption of ions such as sodium and potassium that gives an osmotic effect (Huang etal.,2005), Vitamin C increases the excretion of oxalate or uric either through the kidneys. This is because vitamin $\mathrm{C}$ tend to bind calcium and uric thereby reducing the amount of uric acid in the body. Vitamin C acts as an antioxidant that can reduce oxidative stress and inflammation that can lower uric acid sentesis (Niu, Kristina, Paul, Michel, \& R, 2005).

Body mass index is a tool or a simple way to monitor the nutritional status of adults, especially those relating to the deficiency and overweight (Kemenkes RI, 2011). Respondents in this study has the weight and height proportionally so that the nutritional status respnden mostly normal.

correlation test results Pearson obtained by value $p=0.117$ (sig> 0.05 ) so that we can conclude there is no significant relationship between BMI and uric acid levels respondents. This indicates that the blood uric acid levels are not only determined by one factor alone but by various other factors include sex, age, kidney function, and content of purines in foods. This contrasts with the theory that overweight mainly BMI> $25 \mathrm{~kg} / \mathrm{m}^{2}$ can increase uric acid levels and also withstand heavy burden on supporting joints of the body (Purwaningsih, 2009). The risks increase if the accumulation of fat in the abdomen. Obesity will be the release of excessive free fatty acids in the circulation which causes insulin resistance which can lead to increased uric acid (Wisesa \& Suastika, 2009)

Based on research conducted by Choi et al. (1998) found that dietary factors with the risk of gout is not overly dependent on body mass index, and in men who consume alcohol. Similar studies show that high uric acid levels (hyperuricemia) is not only experienced by obese subjects but also in the non-obese. This may be due to genetic factors that contribute to elevated uric acid levels and reduced physical activity (Rau, Ongkowijaya, \& Kawengian, 2015). Another study found their high levels of uric acid in the respondents overweight and obesity with the possible result of a decrease in renal excretion of uric acid due to insulin resistance and hyperinsulinemia occurring in the state of overweight and obesity (Karimba, Kaligis, and Purwanto, 2013).

\section{CONCLUSIONS AND RECOMMENDATIONS}

The independent variable which is significantly related to the variable uric acid level are Consumption of food sources of purines, the intake of protein, fat, vitamin $\mathrm{C}$. The independent variable which is not significantly related to the variable uric acid level are carbohydrate intake and BMI. Suggested for adult males who lived in the village of Bukit Duri to limit eating foods high in purine source, consume protein, fat as needed, increasing the consumption of vegetables and fruits as well as maintaining ideal body weight. It is expected that further researchers can examine other determinants. 


\section{REFERENCES}

Nelson, E.. Kendrad, Williams , M. Carolyn. (2014). Disease Epidemiology-3 rd, the United State of America

Choi, H. K., Gao, X., \& Curhan, G. (2009). Vitamin C Intake and The Risk of Gout in Men A Prospective Study. Journal of Arch Intern Med, 169

Choi, H. K., Karen, A., Elizabeth, W. K., Walter, W., \& Gary, C. (2004). Purine Rich Foods Dairy and Protein Intake and Risk of Gout in Men. The New England Journal of Medication, 93-103

Choi, H.K., Mount, D. B., Reginato, A., M. (2005). Pathogenesis of gout. Journal of Annals of Internal Medicine, 499-516

Darmawan, J., J, R. J., \& H, N. (2003). The Efect of Control and Self Medication of Chronic Gout in a Developing Country. Outcome after10 Years. Journal of Rheumatol, 43. Retrieved Oktober 15, 2016, dari www.ncbi.nlm.nih.gov.

Depkes RI. (2009). Profil Kesehatan Indonesia. Jakarta: Kementrian Kesehatan

Dianati, N. A, Gout and hiperuricemia.(2015). Journal of Majority, 4, 83

Diantari, E., \& Candra, A. (2013). Pengaruh Asupan Purin dan Cairan terhadap Kadar Asam Urat Wanita Usia 50-60 tahun di Kecamatan Gajah Mungkur, Semarang. Journal of Nutririon Collage, 44-49

Gao, X., Curhan, G., Forman, J. P., Ascherio, A., \& Choi, H. K. (2008). Vitamin C intake and Serum Uric Acid Concentration in Men. Journal of Rehumatol, 1853-1858

Hartono, Andry. (2004). Terapi Gizi dan Diet Rumah Sakit. Jakarta: Buku Kedokteran EGC

Hayman, S., Marcason, W. (2009). Gout: Is a Purine Restricted Diet Still Recommended?. Journal of the Academy of Nutrition and Dietetics, 109

Hidayat, R, Gout dan Hiperurisemia. (2009). Journal of Medicinus, 22. Retrieved September 22, 2016, from www.dexamedica.com.

Huang, Y. H., Appel, L. J., Choi, M. J., Gelber, A. C., Charleston, J., Norkus, E. P., \& Miller, E. R. . (2005). The Effetc of Vitamin C Supplementation on Serum Concentrations of Uric Acid. Journal of Athritis and Rheumatism, 1843

Ilyas, N. O., Suprihartono, F. A., \& Dewi, M. (2014). Beberapa Faktor yang Berhubungan dengan Kejadian Hiperurisemia pada Pasien Rawat Jalan di RS Dustira Cimahi. Jurnal Gizi Indonesia, 91-100

Karimba, A., Kaligis, S., \& Purwanto, D. (2013). Gambaran Kadar Asam Urat pada Mahasiswa Angkatan 2011 Fakultas Kedokteran Universitas Sam Ratulangi dengan Indeks Massa Tubuh >23 kg. Journal e-Biomedik (eBM), 122-128

Kemenkes RI. (2011). Standar Antropometri Penilaian Status Gizi Anak. Jakarta: Direktorat Bina Gizi

Kurnia, M. (2010) Peran Gizi dalam Penatalaksanaan Hiperurisemia dan Pirai. Damianus Journal of Medicine, 121-128

Lina, N., \& Setiyono, A. (2014). Analisis Kebiasaan Makan yang Menyebabkan Peningkatan Kadar Asam Urat. Jurnal Kesehatan Komunitas Indonesia, 1004-1016

Lingga, Lanny. (2012). Bebas Penyakit Asam Urat Tanpa Obat. Jakarta: PT. Agro Media Pustaka,

Mulyasari, Ade. (2015). Faktor Asupan Zat Gizi yang Berhubungan dengan Kadar Asam Urat Darah Wanita Postmenopause. SKRIPSI: Universitas Diponegoro

Murray, R. K., Granner, D. K., \& Rodwell, V. W. (2006). Biokimia Harper (edisi 27 ed.). Jakarta: Penerbit Buku Kedokteran EGC 
Niu, T., Kristina, D. T., Paul, D. G., Michel, D. H., \& R, D. M. (2005). Antioxidant treatment prevent renal damage and dysfunction and reduce arterial, presure in salt sensitive hypertension. American Health Assosiation Inc, 934-939

Purwaningsih, Tinah. (2009). Faktor-Faktor Resiko Hiperurisemia pada Studi Kasus di Rumah Sakit Umum Kardinah Kota Tegal. Diponegoro University E-Journal. Retrieved Oktobr 22, 2016, from http://.undip.ac.id/24334.

Rau, E., Ongkowijaya, J., \& Kawengian, V. ,(2015). Perbandingan Kadar Asam Urat pada Subyek Obes dan Non-Obes di Fakultas Kedokteran Universitas Sam Ratulangi Manado. Journal e-Clinic (eCI), 3, 663-669

Riskesdas. (2013). Laporan Nasional 2010. Jakarta: Badan Penelitian dan Pengembangan KesehatanDeparteen Kesehatan RI

Sandjaya, H. (2014). Buku Sakti Pencegah dan Penangkal Asam Urat. Yogyakarta: Mantra Books,

Soejoeti, Sunanti Z. (2009). Konsep Sehat. Sakit dan Penyakit dalam Konteks Sosial Budaya

Suroso Joewono dan hafid algristian. (2011). buku (E-Book) Asam Urat cetak I, Jakarta, penebar plus (penebar swadaya grup)

Villegas, R., Xiang, Y. B., Elasy, T., Cai, H., Linton, M. F., Fazio, S., Zheng, W., et al. (2012). Purine-Rich Foods Protein Intake, and The Prevalence of Hyperuricemia . Journal of The Sanghai Men's Health Study, 409-416

Wang, D. D., Sievenpiper, J. L., \& Souza, J. R. (2012). The Effect of Fructose Intake on Serum Uric Acid Vary among Controlled Dairy Trials. The Journal of Nutrition, 916923 